\title{
Explore on Design Method of Eco-renewal Projects in European Block Level
}

\author{
Qian ZHAO, Shanghai Tongji Urban Planning \& Design Institute, China
}

\begin{abstract}
China has entered the era of ecological civilization, it is necessary to explore a path of sustainable development. This study collect block level cases of environment improvement in Europe from the UN - HABITAT Best Practices Database. On this basis, complement other related research. In addition, supplement the eco-renewal cases by my on-the-spot investigation in Europe. Collect all cases together, and cancel the cases which are out of topic, ultimately select 41 cases of the block level, finally establish the case base of eco-renewal projects in block level. Then, refine the design methods of eco-renewal from each case, collect and sort the methods from above cases to summarize and concise universal ecological design method, to explore the sustainable ecological design rules and regularities of distribution. My study provides the advanced ecological spectrum of design methods for China's city blocks sustainable update. Make a contribution to the urban transformation development of developing countries in the future.
\end{abstract}

\section{Keywords}

Sustainable Development, Eco-renewal, Design method, Block level

\section{The introduction}

China is at the node of rapid urbanization development. With the rapid growth of urban population and the continuous expansion of urban construction area, the contradiction between resources, environment and population is greatly aggravated. Therefore, it is extremely urgent to build a sustainable ecological civilization society. In recent years, the concept of ecological design has gradually penetrated into the theory and practice of urban planning and design, and become a powerful tool to solve the important issues such as environmental disturbance and survival crisis in the new era.

At present, a large number of "eco-cities", "sustainable communities", "green buildings" and other concepts emerging in China originate from Europe, and a large number of successful experiences can be obtained in representative European cities. The purpose of this paper is to study the design methods of ecological reconstruction projects in Europe, with emphasis on the study of ecological design methods. Selected and sorted out the ecological reconstruction cases with exemplary significance at the European plot level, analyzed and compared the ecological design methods adopted in the construction and development process of each case horizontally and vertically, extracted the ecological design methods and measures, and established the database of research objects. Through the comparison and analysis of different cases, a set of ecological design method system with universal significance is explored, which can be reasonably applied to the sustainable development and construction of large, medium and small cities in China. 


\section{Case Base construction of European ecological reconstruction projects}

This paper focuses on the analysis of the design methods in the European Ecological Practice project. First, the case base of the European Ecological improvement Project was established. Most of the cases in the case base came from the UN-Habitat Best Practices Database, and 93 cases related to the improvement of the European ecological environment were collected from the Database.

Un-habitat's best Practice database is a free public access database with many effective solutions through the submission of cases by national, local governments and social organizations to collect outstanding practices in social, economic, environmental and other aspects. The database contains 1,281 best practice cases from more than 100 countries, including 299 cases from Europe (including the former Soviet Union). Will Europe (including the former Soviet union) best practice cases was divided into 17 classes, respectively is: disease, information use, architecture and urban design, children, youth and old age, land use management, gender, techniques and tools, production and consumption, infrastructure, economic development, reducing poverty, public cultural diversity, social services and city planning, urban governance, housing and environmental management. Among them, 93 cases involved the environment, accounting for the highest proportion (32.4\%) in European best practice cases.

On this basis, 88 cases involving ecological renovation projects in relevant research fields are supplemented, which are mainly from the SURBAN Urban Development Best Practices database.

Extract un-habitat best practices the reconstruction of the database on the environmental management of Europe's best practice case, supplement related research of ecological research and practice of ecological case, after the merger to comb filter, remove the repeat out topic case, forming putted forward in this paper, the author studies on the ecological rebuilding the project. There are 189 cases in the database, covering 138 European cities in 32 European countries.

\subsection{Time distribution characteristics of European ecological renovation projects}

The change rule of the number of analysis cases and the project design time is shown in Figure 1, which directly reflects the development law of ecological practice in Europe. The ecological practice projects in various countries began to increase slowly from 1970 to 1997, and then increased rapidly for the first time. In 1999, they fell back. Around 2000, the number of ecological practice projects reached the peak of growth, which was the most active period for countries to carry out ecological practice. After 2001, the growth of ecological reconstruction projects slowed down again and showed a trend of wavy and stable growth in the following 14 years.

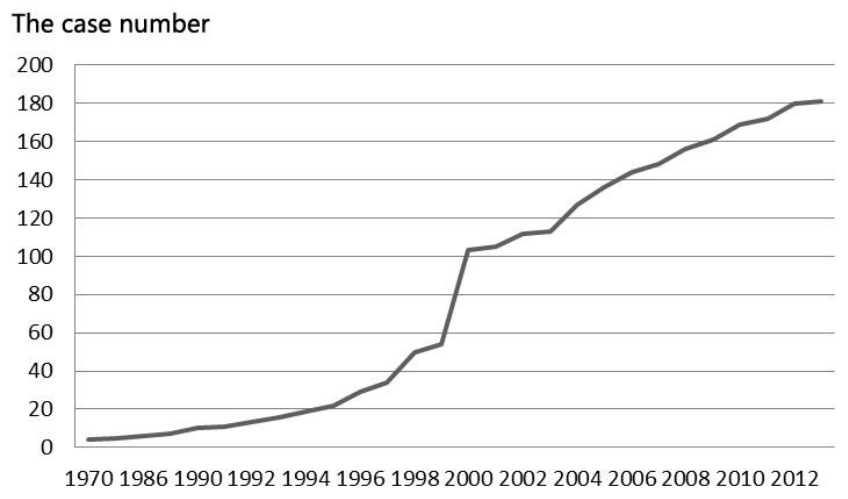

Figure 1. Variation pattern of the number of cases and design time of European ecological renovation projects. Source: The SURBAN Urban Development Best Practices Database.

\subsection{Spatial distribution characteristics of European ecological renovation projects}

In space, the European countries are divided into northern Europe, Eastern Europe, central Europe, Western Europe and southern Europe by geographical location. Among them, northern Europe includes 
Norway, Denmark, Finland, Sweden and Iceland; Eastern European countries include Russia, Belarus, Ukraine, Lithuania, Estonia, Latvia and Moldova; Cities in central Europe include Germany, Poland, the Czech Republic, Austria, Hungary, Slovakia and Liechtenstein in central Europe; Western European countries are The United Kingdom, Ireland, France, the Netherlands, Luxembourg, Belgium and Monaco; Southern European countries include Spain, Portugal, Italy, Greece, Romania, Serbia, Monaco and other countries. According to the national. The number of ecological renovation projects falls in space, as shown in FIG. 2 and FIG. 3. From the spatial perspective, the case base covers a wide range, with a certain number of cases distributed in all five regions, mainly in Central Europe, Northern Europe and Western Europe. The countries with more ecological improvement projects are Denmark, Sweden, Russia, Spain, Italy, Bulgaria, France, Britain, Austria, Poland and Germany, as shown in Table 1.

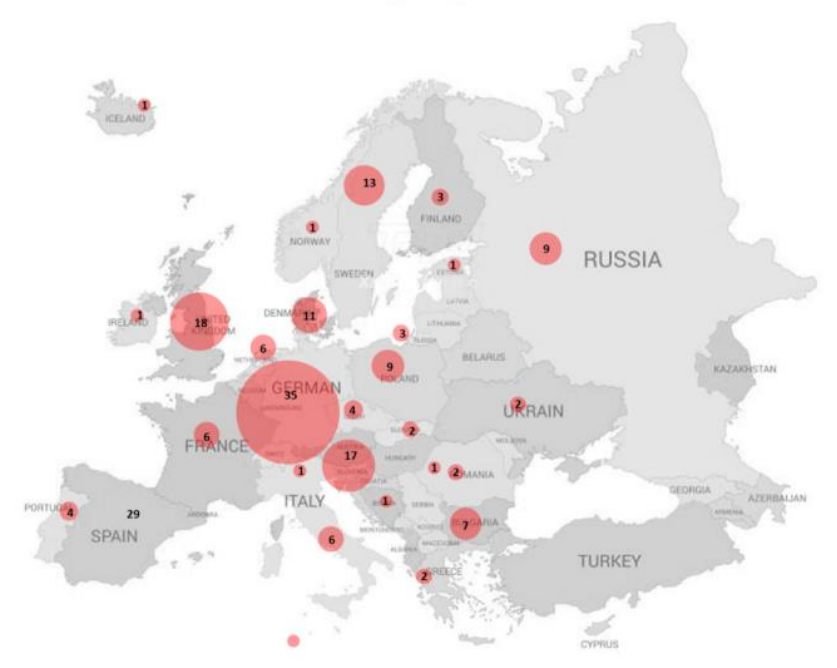

Figure 2. Spatial distribution of the number of ecological improvement cases in European countries in the case base. Source: The SURBAN Urban Development Best Practices Database.

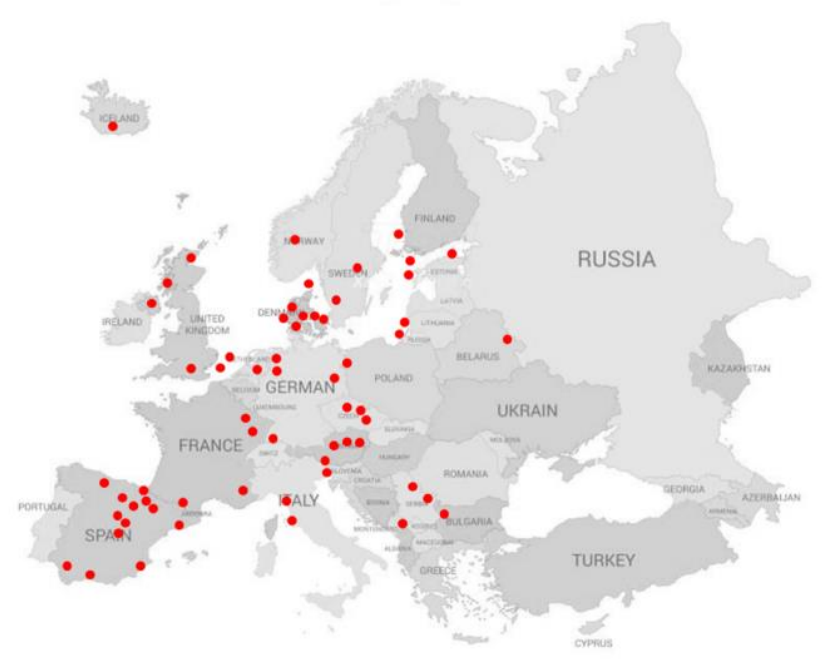

Figure 3. European ecological improvement cases in the case base are arranged by city. Source: The SURBAN Urban Development Best Practices Database.

Table 1. The top 10 countries in total ecological improvement projects. Source: The SURBAN Urban Development Best Practices Database.

\begin{tabular}{|l|l|l|l|l|l|}
\hline region & $\begin{array}{l}\text { Northern } \\
\text { Europe }\end{array}$ & $\begin{array}{l}\text { Western } \\
\text { Europe }\end{array}$ & Central Europe & $\begin{array}{l}\text { Eastern } \\
\text { Europe }\end{array}$ & southern Europe \\
\hline
\end{tabular}




\begin{tabular}{|l|l|l|l|l|l|l|l|l|l|l|l|}
\hline $\begin{array}{l}\text { countri } \\
\text { es }\end{array}$ & $\begin{array}{l}\text { Denm } \\
\text { ark }\end{array}$ & $\begin{array}{l}\text { Swed } \\
\text { en }\end{array}$ & $\begin{array}{l}\text { Franc } \\
\text { e }\end{array}$ & $\begin{array}{l}\text { Brit } \\
\text { ain }\end{array}$ & $\begin{array}{l}\text { Aust } \\
\text { ria }\end{array}$ & $\begin{array}{l}\text { Polan } \\
\text { d }\end{array}$ & $\begin{array}{l}\text { Germ } \\
\text { any }\end{array}$ & Russia & Spain & Italy & Bulgaria \\
\hline $\begin{array}{l}\text { The } \\
\text { number }\end{array}$ & 11 & 13 & 6 & 18 & 17 & 9 & 35 & 9 & 29 & 6 & 7 \\
\hline $\begin{array}{l}\text { The } \\
\text { order }\end{array}$ & 6 & 5 & 9 & 3 & 4 & 7 & 1 & 7 & 2 & 9 & 8 \\
\hline
\end{tabular}

\subsection{European ecological renovation project case type characteristics}

The plot level refers to the ecological design within the social living area that makes residents interconnected in life, and the ecological reconstruction for urban space node elements, including zerocarbon ecological community project, energy-saving renovation project of a residential area, community waste composting project and community clean and healthy project.

Table 2.Proportion of European eco-renovation projects at the plot level. Source: The SURBAN Urban Development Best Practices Database.

\begin{tabular}{|l|l|}
\hline Spatial scale & Block level \\
\hline The case number & 42 \\
\hline The proportion & $22.2 \%$ \\
\hline
\end{tabular}

\section{Construction of European ecological design method library}

\subsection{Principle of classification of ecological design methods}

The classification principles of case studies usually include inclusion, exclusion (non-repetition), essentiality, objective and objectivity. According to the research content of this paper, the classification principles suitable for this paper are formulated as follows:

All design methods involved in ecology or sustainability in the case;

Try not to repeat the design method;

Moderate transformation of special cases in the classification process makes it universal.

\subsection{Description of ecological design method type division}

The cases at the plot level in the case base of ecological reconstruction projects are extracted, and the respective types of ecological design methods are further subdivided to reconstruct the case base of ecological design methods.

The urban plot level refers to the ecological design of the interconnected communities in life, aiming at improving the quality of residents' indoor and outdoor living environment. It involves the ecological elements of the community, the economic, social and livable elements of the community. Among them, ecological elements: energy, water, matter, air, earth and generation run through each spatial level from top to bottom, presenting different design elements at different spatial levels, as shown in Table 3 .

Table 3 Classification framework of urban ecological design methods at various spatial levels. Source: The SURBAN Urban Development Best Practices Database.

\begin{tabular}{|c|c|c|c|c|c|c|c|c|c|c|c|}
\hline \multicolumn{6}{|c|}{ Material energy design } & \multicolumn{2}{|c|}{ Physical space design } & \multicolumn{4}{|c|}{ Design and implementation mechanism } \\
\hline $\begin{array}{l}\text { en } \\
\text { er }\end{array}$ & $\begin{array}{l}\mathrm{W} \\
\text { at }\end{array}$ & $\begin{array}{l}\text { ob } \\
\text { je }\end{array}$ & $\begin{array}{l}\text { ga } \\
\text { s }\end{array}$ & $\begin{array}{l}\text { gr } \\
\text { ou }\end{array}$ & $\begin{array}{l}\text { biolo } \\
\text { gical }\end{array}$ & $\begin{array}{l}\text { Space } \\
\text { utilization }\end{array}$ & $\begin{array}{l}\text { road } \\
\text { traffic }\end{array}$ & $\begin{array}{l}\text { The green } \\
\text { substrate }\end{array}$ & $\begin{array}{l}\text { managem } \\
\text { ent }\end{array}$ & social & $\begin{array}{l}\text { econo } \\
\text { mic }\end{array}$ \\
\hline
\end{tabular}




\begin{tabular}{|l|l|l|l|l|l|l|l|} 
gy & er & ct & nd & & & & \\
\hline
\end{tabular}

\section{Description of types of ecological design methods}

According to the above classification, the ecological design methods at each level are further summarized, and the repetitive and irrelevant methods are removed to classify the extracted ecological design methods. A total of 97 design methods for ecological reconstruction projects at the plot level were sorted out. There are 60 design techniques mainly applicable to reconstruction projects. According to three design types of material energy design, physical space design and design implementation mechanism, there are 38,32 and 27 respectively.

\subsection{Classification of ecological design methods at the plot level}

The design methods of the plot level are classified, as shown in Table 4.

Table 4 Classification of ecological design methods at the plot level. Source: The SURBAN Urban Development Best Practices Database.

\begin{tabular}{|c|c|c|c|}
\hline Type & Field & Direction & $\begin{array}{l}\text { Subdivision of ecological design methods (grey areas are mainly } \\
\text { used for reconstruction projects) }\end{array}$ \\
\hline \multirow{13}{*}{$\begin{array}{l}\text { Material } \\
\text { energy } \\
\text { design }\end{array}$} & \multirow{13}{*}{ energy } & \multirow{12}{*}{$\begin{array}{l}\text { Energy } \\
\text { production }\end{array}$} & $\begin{array}{l}\text { According to the terrain conditions, the main and auxiliary } \\
\text { renewable energy use types are selected, including solar energy, } \\
\text { tidal energy, geothermal energy, biomass energy and wind energy }\end{array}$ \\
\hline & & & $\begin{array}{l}\text { Renewable energy is used in combination with conventional energy, } \\
\text { such as building large wind farms to meet more than } 70 \% \text { of the } \\
\text { electricity supply, supplemented by diesel generators as regulation }\end{array}$ \\
\hline & & & $\begin{array}{l}\text { Based on the closed material cycle, the excrement is converted into } \\
\text { biogas, which, together with vegetable oil, is used as fuel power and } \\
\text { heat for cogeneration }\end{array}$ \\
\hline & & & $\begin{array}{l}\text { The biogas collector and UVP pump station are converted to biogas } \\
\text { as a source of heat energy to supply hot water }\end{array}$ \\
\hline & & & $\begin{array}{l}\text { Fast-growing wood is used as renewable fuel instead of coal and } \\
\text { other traditional fossil fuels }\end{array}$ \\
\hline & & & $\begin{array}{l}\text { Large areas of solar photovoltaic panels are laid on a south-facing } \\
\text { slope }\end{array}$ \\
\hline & & & Build a wind turbine on top of the mountain \\
\hline & & & $\begin{array}{l}\text { Through the integrated solar energy collector of the building, the } \\
\text { heat is transferred to the heating center for heating each household }\end{array}$ \\
\hline & & & $\begin{array}{l}\text { Use solar auxiliary natural ventilation, solar auxiliary heat recovery } \\
\text { ventilation system, solar heating hot water }\end{array}$ \\
\hline & & & $\begin{array}{l}\text { Small islands are built with } 100 \% \text { renewable energy systems, mainly } \\
\text { wind and solar energy }\end{array}$ \\
\hline & & & Set up the energy storage system and backup system \\
\hline & & & Use locally produced vegetable oil as an energy supplement \\
\hline & & $\begin{array}{l}\text { Energy } \\
\text { delivery }\end{array}$ & $\begin{array}{l}\text { It is suggested that the district heating network should be } \\
\text { incorporated into the district central heating system }\end{array}$ \\
\hline
\end{tabular}




\begin{tabular}{|c|c|c|c|}
\hline Type & Field & Direction & $\begin{array}{l}\text { Subdivision of ecological design methods (grey areas are mainly } \\
\text { used for reconstruction projects) }\end{array}$ \\
\hline & & $\begin{array}{l}\text { Energy } \\
\text { consumptio } \\
\mathrm{n}\end{array}$ & $\begin{array}{l}\text { Promote and promote low energy consumption electrical appliances } \\
\text { and lighting fixtures }\end{array}$ \\
\hline & \multirow{13}{*}{$\begin{array}{l}\text { The } \\
\text { water } \\
\text { resourc } \\
\text { es }\end{array}$} & $\begin{array}{l}\text { Water } \\
\text { resources } \\
\text { protection }\end{array}$ & $\begin{array}{l}\text { Plan ecological corridor along river road and water system and } \\
\text { utilize water and soil conservation }\end{array}$ \\
\hline & & \multirow{7}{*}{$\begin{array}{l}\text { Water } \\
\text { resource } \\
\text { utilization }\end{array}$} & $\begin{array}{l}\text { Rainwater is collected on the roof and seepage of the ground in the } \\
\text { open space }\end{array}$ \\
\hline & & & Ground-floor residents use private gardens to collect rainwater \\
\hline & & & Open ditch drainage pipe combination, reduce the loss \\
\hline & & & $\begin{array}{l}\text { Improve the permeability of road surface and collect rainwater as } \\
\text { much as possible }\end{array}$ \\
\hline & & & $\begin{array}{l}\text { Install water-saving devices in each household, such as new } \\
\text { household water valves, meters and flow restrictors }\end{array}$ \\
\hline & & & $\begin{array}{l}\text { Update pipework and water sanitation system, separate supply of hot } \\
\text { and cold water }\end{array}$ \\
\hline & & & $\begin{array}{l}\text { Improve water management at the grass-roots level, charge water } \\
\text { consumption by household, and reduce water consumption }\end{array}$ \\
\hline & & \multirow{3}{*}{$\begin{array}{l}\text { Sewage } \\
\text { treatment }\end{array}$} & $\begin{array}{l}\text { The polluted water near the river will be filtered by halophytes } \\
\text { before entering the area to filter and purify the polluted soil and } \\
\text { prevent pollutants and heavy metals from entering the river }\end{array}$ \\
\hline & & & $\begin{array}{l}\text { Domestic sewage is collected from the sewage pipe to the reed deep } \\
\text { pool for purification }\end{array}$ \\
\hline & & & $\begin{array}{l}\text { Sewage collection is biotreated (uv exposure and vertical biofilter) } \\
\text { for reuse }\end{array}$ \\
\hline & & \multirow{2}{*}{$\begin{array}{l}\text { Reuse of } \\
\text { waste water }\end{array}$} & $\begin{array}{l}\text { Improve the rainwater collection and recycling system, rainwater } \\
\text { and domestic sewage are cleaned and reused by gravel bed filter }\end{array}$ \\
\hline & & & $\begin{array}{l}\text { It is used for landscape water of park green space, irrigation garden, } \\
\text { toilet washing room, reserve fire water and so on }\end{array}$ \\
\hline & \multirow{5}{*}{ Waste } & \multirow{2}{*}{$\begin{array}{l}\text { Waste } \\
\text { produce }\end{array}$} & $\begin{array}{l}\text { The building materials are made of natural wood and } \\
\text { environmentally friendly materials instead of polluting fossil fuels }\end{array}$ \\
\hline & & & $\begin{array}{l}\text { We will promote the use of organic cotton bags instead of plastic } \\
\text { bags, reduce animal mortality and chemical soil pollution, and } \\
\text { increase agricultural fertility }\end{array}$ \\
\hline & & \multirow{2}{*}{$\begin{array}{l}\text { Waste } \\
\text { collection }\end{array}$} & $\begin{array}{l}\text { Centralized recycling of household plastic products, separate } \\
\text { collection of green organic waste, mixed dry waste recycling }\end{array}$ \\
\hline & & & $\begin{array}{l}\text { Supplement the recycling centre and add street furniture such as } \\
\text { rubbish bins }\end{array}$ \\
\hline & & Waste & Organic waste composting, implement home self composting \\
\hline
\end{tabular}




\begin{tabular}{|c|c|c|c|}
\hline Type & Field & Direction & $\begin{array}{l}\text { Subdivision of ecological design methods (grey areas are mainly } \\
\text { used for reconstruction projects) }\end{array}$ \\
\hline & & recycling & program \\
\hline & & & Waste recovery and utilization capacity, such as methane \\
\hline & & & Construction waste recycling, encourage the reuse of old furniture \\
\hline & \multirow{4}{*}{$\begin{array}{l}\text { Biodive } \\
\text { rsity }\end{array}$} & $\begin{array}{l}\text { Protecting } \\
\text { diversity }\end{array}$ & $\begin{array}{l}\text { Introduce birds and use greenhouses to grow fruits, vegetables and } \\
\text { flowers for biodiversity management }\end{array}$ \\
\hline & & \multirow{3}{*}{$\begin{array}{l}\text { Vegetation } \\
\text { planting }\end{array}$} & Planting cedars and other natural barriers to wind and shade \\
\hline & & & $\begin{array}{l}\text { Designed in conjunction with botanists, trees, shrubs and herbs can } \\
\text { be adapted to local conditions to purify the air, shade the sun and } \\
\text { prevent noise }\end{array}$ \\
\hline & & & Illegal deforestation is strictly prohibited \\
\hline \multirow{13}{*}{$\begin{array}{l}\text { Physical } \\
\text { space } \\
\text { design }\end{array}$} & \multirow{13}{*}{$\begin{array}{l}\text { Space } \\
\text { utilizati } \\
\text { on }\end{array}$} & \multirow{5}{*}{$\begin{array}{l}\text { Land } \\
\text { layout }\end{array}$} & $\begin{array}{l}\text { Compact land layout, intensive land use, high density building } \\
\text { design }\end{array}$ \\
\hline & & & $\begin{array}{l}\text { The commercial agglomeration around the railway station not only } \\
\text { satisfies the employment but also improves the land value }\end{array}$ \\
\hline & & & $\begin{array}{l}\text { The city with good landscape resources and linear land layout can } \\
\text { realize the evenness of urban landscape }\end{array}$ \\
\hline & & & $\begin{array}{l}\text { Balance the distribution of resources between urban center and } \\
\text { surrounding areas, improve the quality of public space, and attract } \\
\text { lost youth back to the community }\end{array}$ \\
\hline & & & $\begin{array}{l}\text { Provide a certain proportion of social housing and security housing } \\
\text { as social welfare }\end{array}$ \\
\hline & & & $\begin{array}{l}\text { Protect the historic core area and respect the original urban structure } \\
\text { and texture }\end{array}$ \\
\hline & & $\begin{array}{l}\text { Heritage } \\
\text { regeneratio }\end{array}$ & $\begin{array}{l}\text { The old factory was transformed into a multifunctional commercial } \\
\text { building complex, accommodating commercial services, culture, } \\
\text { administration, sports and other functions }\end{array}$ \\
\hline & & & $\begin{array}{l}\text { Preserve the unique shape of the original industrial buildings and } \\
\text { reconstruct the ecological museum to display the cultural heritage of } \\
\text { the region }\end{array}$ \\
\hline & & & $\begin{array}{l}\text { Rationally organized multiple Spaces in the community: public, } \\
\text { semi-public and private Spaces }\end{array}$ \\
\hline & & & $\begin{array}{l}\text { The community is well equipped with public facilities: commercial } \\
\text { center and bathroom, laundry, etc }\end{array}$ \\
\hline & & $\begin{array}{l}\text { Communit } \\
\text { y (single) }\end{array}$ & $\begin{array}{l}\text { The community should build a central garden (residents can rent a } \\
\text { garden to grow), a cultural center and a kindergarten, and provide a } \\
\text { variety of activities for children and teenagers }\end{array}$ \\
\hline & & & $\begin{array}{l}\text { Within the same plot, there are various types of buildings with } \\
\text { various options to meet the needs of different age groups }\end{array}$ \\
\hline & & & Provide a variety of housing types for residents of different ages and \\
\hline
\end{tabular}




\begin{tabular}{|c|c|c|c|}
\hline Type & Field & Direction & $\begin{array}{l}\text { Subdivision of ecological design methods (grey areas are mainly } \\
\text { used for reconstruction projects) }\end{array}$ \\
\hline & & & RACES \\
\hline & & & $\begin{array}{l}\text { Encourage home office, provide home office } \mathrm{SOHO} \text { and fitness, } \\
\text { recreation facilities }\end{array}$ \\
\hline & & & $\begin{array}{l}\text { The residential area is connected with the surrounding green space } \\
\text { to reserve natural air passages. Non-motorized lanes and sidewalks } \\
\text { are set along the natural air corridors to promote the natural } \\
\text { ventilation of street buildings in summer and improve the micro- } \\
\text { climate environment }\end{array}$ \\
\hline & & & $\begin{array}{l}\text { Reducing the number of single-family homes, the layout of the } \\
\text { townhouse reduces the exchange of heat between the interior and } \\
\text { exterior of the building, facilitates natural ventilation and lighting, } \\
\text { and creates block space }\end{array}$ \\
\hline & & & $\begin{array}{l}\text { The enclosed layout of the building reduces energy and resource } \\
\text { consumption, creates a pleasant green public space in the center, and } \\
\text { bans the passage of motor vehicles inside }\end{array}$ \\
\hline & & & $\begin{array}{l}\text { The layout orientation of the building (east west direction) should be } \\
\text { conducive to solar energy collection. The south facade wall should } \\
\text { be used to gather energy, and the north facade should be installed } \\
\text { with air collector (the south window should be enlarged and the } \\
\text { north window reduced). }\end{array}$ \\
\hline & & & $\begin{array}{l}\text { Energy-saving and environmental friendly materials (silica gel salt } \\
\text { coating, etc.) are selected for thermal insulation and heat } \\
\text { preservation design, such as chlorofluorocarbon free, larch siding, } \\
\text { rubber floor and pine window frame, etc., to save energy and reduce } \\
\text { energy loss }\end{array}$ \\
\hline & & & $\begin{array}{l}\text { The exterior walls are made of ceramic, wood and limestone, with } \\
\text { wood and plaster ceilings and Windows }\end{array}$ \\
\hline & & & $\begin{array}{l}\text { Demolition and river in the gravel, waste wood chips can be } \\
\text { recycled as building materials }\end{array}$ \\
\hline & & & $\begin{array}{l}\text { Connect the heat pipes of the concrete exterior wall to ensure air } \\
\text { circulation }\end{array}$ \\
\hline & & & $\begin{array}{l}\text { The insulation technology of environmental protection material is } \\
\text { adopted for the building wall, and the external wall of thermal } \\
\text { insulation is added and the thickness of the building wall is } \\
\text { increased to make the building thermal insulation }\end{array}$ \\
\hline & & & $\begin{array}{l}\text { The Windows were replaced with two and three layers of glass filled } \\
\text { with argon, and wooden window frames were used }\end{array}$ \\
\hline & & & Basement, ceiling joints do insulation treatment \\
\hline & & & Close balconies and corridors to reduce heat loss \\
\hline & & & $\begin{array}{l}\text { The cold space is arranged in the north direction, the hot space in the } \\
\text { south direction, and the curved south-facing elevation maximizes }\end{array}$ \\
\hline
\end{tabular}




\begin{tabular}{|c|c|c|c|}
\hline Type & Field & Direction & $\begin{array}{l}\text { Subdivision of ecological design methods (grey areas are mainly } \\
\text { used for reconstruction projects) }\end{array}$ \\
\hline & & & the utilization of solar energy resources \\
\hline & & & $\begin{array}{l}\text { Natural ventilation system is installed in the room to improve indoor } \\
\text { air quality }\end{array}$ \\
\hline & & & Create a thermal buffer for your living space \\
\hline & & & $\begin{array}{l}\text { The construction of community infrastructure adopts the } \\
\text { construction method of low energy consumption }\end{array}$ \\
\hline & & & $\begin{array}{l}\text { To monitor the content of harmful substances in the air of new } \\
\text { houses to meet the standards for new houses }\end{array}$ \\
\hline & & & $\begin{array}{l}\text { Develop a standard grade for zero-carbon housing and automatically } \\
\text { monitor residents' resource consumption }\end{array}$ \\
\hline & \multirow{8}{*}{$\begin{array}{l}\text { The } \\
\text { road } \\
\text { traffic }\end{array}$} & \multirow{2}{*}{$\begin{array}{l}\text { Bicycle } \\
\text { traffic }\end{array}$} & $\begin{array}{l}\text { Connect to form a finger-like bicycle road network, provide a good } \\
\text { bicycle environment, convenient access to the public green space }\end{array}$ \\
\hline & & & Supporting services to build a number of bicycle parking stations \\
\hline & & \multirow{3}{*}{$\begin{array}{l}\text { Public } \\
\text { transport }\end{array}$} & $\begin{array}{l}\text { Improve the network of public transportation lines and create } \\
\text { circular paths to minimize pollution }\end{array}$ \\
\hline & & & $\begin{array}{l}\text { Strengthen the link between the site and the city centre by } \\
\text { complementing public transport such as fast rail or light rail lines }\end{array}$ \\
\hline & & & $\begin{array}{l}\text { It is recommended that bus stations not more than } 300 \text { meters from } \\
\text { residential areas be set up on main roads }\end{array}$ \\
\hline & & \multirow{3}{*}{$\begin{array}{l}\text { Motor } \\
\text { vehicle } \\
\text { traffic }\end{array}$} & $\begin{array}{l}\text { The plot of land is divided into three parts: pedestrian zone, } \\
\text { restricted zone and slow-moving zone }\end{array}$ \\
\hline & & & $\begin{array}{l}\text { Motor vehicles are placed underground, using the terrain as a semi- } \\
\text { underground parking lot }\end{array}$ \\
\hline & & & $\begin{array}{l}\text { The use of low-quality fuels will be banned, and the use of } \\
\text { hydrogen-powered cars and electric vehicles will be encouraged, as } \\
\text { will the use of densely packed refuelling stations and tram charging } \\
\text { stations }\end{array}$ \\
\hline & \multirow{5}{*}{$\begin{array}{l}\text { The } \\
\text { green } \\
\text { substrat } \\
\text { e }\end{array}$} & \multirow{5}{*}{$\begin{array}{l}\text { The park } \\
\text { green space }\end{array}$} & $\begin{array}{l}\text { Balance public and private green space and ensure that at least half } \\
\text { of it is open to the public }\end{array}$ \\
\hline & & & $\begin{array}{l}\text { Linear parks are built along the tracks to increase the planting of } \\
\text { flowers, shrubs and trees, and to provide recreational and sports } \\
\text { facilities }\end{array}$ \\
\hline & & & $\begin{array}{l}\text { The community builds more green parks (energy supply sites) to } \\
\text { restore and conserve the ecosystem in and around the pond }\end{array}$ \\
\hline & & & $\begin{array}{l}\text { Renovate and dismantle the buildings with poor quality, reconstruct } \\
\text { the courtyard and reorganize the development space, and increase } \\
\text { the greening of the courtyard }\end{array}$ \\
\hline & & & $\begin{array}{l}\text { Climbing plants are planted on the facade and green terraces on the } \\
\text { roof }\end{array}$ \\
\hline
\end{tabular}




\begin{tabular}{|c|c|c|c|}
\hline Type & Field & Direction & $\begin{array}{l}\text { Subdivision of ecological design methods (grey areas are mainly } \\
\text { used for reconstruction projects) }\end{array}$ \\
\hline \multirow{14}{*}{$\begin{array}{l}\text { Design } \\
\text { and } \\
\text { impleme } \\
\text { ntation } \\
\text { mechani } \\
\text { sm }\end{array}$} & \multirow{10}{*}{$\begin{array}{l}\text { manage } \\
\text { ment }\end{array}$} & $\begin{array}{l}\text { Intelligent } \\
\text { manageme } \\
\mathrm{nt}\end{array}$ & Add community energy management system monitoring facilities \\
\hline & & $\begin{array}{l}\text { Policy } \\
\text { manageme } \\
\text { nt }\end{array}$ & $\begin{array}{l}\text { Communities establish incentive mechanisms to encourage residents } \\
\text { to change their life and consumption habits }\end{array}$ \\
\hline & & \multirow{8}{*}{$\begin{array}{l}\text { Education } \\
\text { and } \\
\text { training }\end{array}$} & $\begin{array}{l}\text { Healthy health systems, courses and group activities, counselling for } \\
\text { young families, women's health and pregnant women }\end{array}$ \\
\hline & & & $\begin{array}{l}\text { To set up community visual arts training courses to promote the } \\
\text { formation of cultural and aesthetic values }\end{array}$ \\
\hline & & & $\begin{array}{l}\text { To organize cultural and art lectures on the theme of ecological } \\
\text { construction and promote ecological tourism and ecological } \\
\text { education }\end{array}$ \\
\hline & & & $\begin{array}{l}\text { Organize community volunteers to carry out activities to clean the } \\
\text { beach and protect the coastal natural environment }\end{array}$ \\
\hline & & & $\begin{array}{l}\text { With the help of charity groups, more and more people are } \\
\text { mobilized to join the protection of biodiversity and cultural heritage }\end{array}$ \\
\hline & & & Establish a biomass oil club to promote the recycling of biomass oil \\
\hline & & & $\begin{array}{l}\text { Experimental ecological renewal was carried out in some plots, and } \\
\text { then the experience was extended to the whole area in an orderly } \\
\text { manner }\end{array}$ \\
\hline & & & $\begin{array}{l}\text { To provide internship and training for the renewable energy } \\
\text { industry, promote the awareness of residents on energy-saving } \\
\text { buildings, and popularize energy-saving technologies and specific } \\
\text { methods of use among residents }\end{array}$ \\
\hline & social & $\begin{array}{l}\text { employmen } \\
\mathrm{t}\end{array}$ & $\begin{array}{l}\text { Establish community-based services such as women's management } \\
\text { centers to provide regular sources of employment and income for } \\
\text { the poor and help reduce poverty }\end{array}$ \\
\hline & \multirow{3}{*}{$\begin{array}{l}\text { econom } \\
\text { ic }\end{array}$} & \multirow{2}{*}{ industry } & $\begin{array}{l}\text { Encourage the production of organic food, launch an organic food } \\
\text { supply program, and organize a monthly organic farmers' market }\end{array}$ \\
\hline & & & $\begin{array}{l}\text { Organize organic farming activities that reduce packaging and } \\
\text { transportation for local farming }\end{array}$ \\
\hline & & capital & $\begin{array}{l}\text { Establish local financial foundations and environmental foundations, } \\
\text { implement financial subsidies, and provide social welfare facilities } \\
\text { and jobs }\end{array}$ \\
\hline
\end{tabular}

\subsection{Distribution characteristics of ecological design methods}

The number of internal material and energy design methods for ecological design at the plot level is equal to that for physical space design, which is about twice the number of design implementation mechanism strategies. The methods are increasingly focused on the sustainable redesign of the plot spatial level and individual buildings. 
Table 5. Quantitative statistics of ecological design methods at the plot level. Source: The SURBAN Urban Development Best Practices Database.

\begin{tabular}{|c|c|c|c|c|c|c|c|c|c|c|c|c|c|c|c|c|c|c|c|}
\hline & \multicolumn{19}{|c|}{ Quantity of material energy design (unit) } \\
\hline total & \multicolumn{19}{|l|}{38} \\
\hline new & \multicolumn{19}{|l|}{13} \\
\hline rebuild & \multicolumn{19}{|l|}{25} \\
\hline & \multicolumn{4}{|c|}{ energy } & \multicolumn{4}{|l|}{ water } & \multicolumn{5}{|c|}{ object } & \multicolumn{2}{|c|}{ gas } & $\begin{array}{l}\text { gr } \\
\text { ou } \\
\text { nd }\end{array}$ & \multicolumn{3}{|c|}{ biology } \\
\hline total & \multicolumn{4}{|l|}{14} & \multicolumn{4}{|l|}{13} & \multicolumn{5}{|l|}{7} & \multicolumn{2}{|l|}{0} & 0 & \multicolumn{3}{|l|}{4} \\
\hline new & \multicolumn{4}{|l|}{5} & \multicolumn{4}{|l|}{3} & \multicolumn{5}{|l|}{2} & \multicolumn{2}{|l|}{0} & 0 & \multicolumn{3}{|l|}{3} \\
\hline rebuild & \multicolumn{4}{|l|}{9} & \multicolumn{4}{|l|}{10} & \multicolumn{5}{|l|}{5} & \multicolumn{2}{|l|}{0} & 0 & \multicolumn{3}{|l|}{1} \\
\hline & $\begin{array}{l}\text { pro } \\
\text { du } \\
\text { cti } \\
\text { on }\end{array}$ & $\begin{array}{l}\text { de } \\
\text { li } \\
\text { ve } \\
\text { ry }\end{array}$ & $\begin{array}{l}\text { di } \\
\text { st } \\
\text { ri } \\
\text { b } \\
\text { ut } \\
\text { io } \\
\text { n }\end{array}$ & $\begin{array}{l}\text { co } \\
\text { ns } \\
\mathrm{u} \\
\mathrm{m} \\
\mathrm{e}\end{array}$ & $\begin{array}{l}\text { Wat } \\
\text { er } \\
\text { reso } \\
\text { urc } \\
\text { es } \\
\text { prot } \\
\text { ecti } \\
\text { on }\end{array}$ & $\begin{array}{l}\text { W } \\
\text { ate } \\
\text { r } \\
\text { res } \\
\text { our } \\
\text { ce } \\
\text { util } \\
\text { iza } \\
\text { tio } \\
\mathrm{n}\end{array}$ & $\begin{array}{l}\mathrm{Se} \\
\mathrm{w} \\
\mathrm{ag} \\
\mathrm{e} \\
\text { tre } \\
\mathrm{at} \\
\mathrm{m} \\
\mathrm{en} \\
\mathrm{t}\end{array}$ & $\begin{array}{l}\text { R } \\
\text { eu } \\
\text { se } \\
\text { of } \\
\text { W } \\
\text { as } \\
\text { te } \\
\text { w } \\
\text { at } \\
\text { er }\end{array}$ & $\begin{array}{l}\text { w } \\
\text { as } \\
\text { te } \\
\text { pr } \\
\text { od } \\
\text { uc } \\
\text { e }\end{array}$ & $\begin{array}{l}\mathrm{W} \\
\text { ast } \\
\mathrm{e} \\
\mathrm{col} \\
\text { lec } \\
\text { tio } \\
\mathrm{n}\end{array}$ & $\begin{array}{l}\text { W } \\
\text { ste } \\
\text { dis } \\
\text { po } \\
\text { al }\end{array}$ & & $\begin{array}{l}\text { Wa } \\
\text { te } \\
\text { ecy } \\
\text { lin } \\
\end{array}$ & $\begin{array}{l}\text { W } \\
\text { as } \\
\text { te } \\
\text { ga } \\
\text { s } \\
\text { ge } \\
\text { ne } \\
\text { ra } \\
\text { te } \\
\text { d }\end{array}$ & $\begin{array}{l}\mathrm{Ai} \\
\mathrm{r} \\
\text { po } \\
\text { llu } \\
\text { tio } \\
\mathrm{n}\end{array}$ & $\begin{array}{l}\text { top } \\
\text { og } \\
\text { rap } \\
\text { hy }\end{array}$ & $\begin{array}{l}\text { Prot } \\
\text { cting } \\
\text { dive } \\
\text { sity }\end{array}$ & & $\begin{array}{l}\text { Ve } \\
\text { get } \\
\text { ati } \\
\text { on } \\
\text { pla } \\
\text { hti } \\
\text { ng }\end{array}$ \\
\hline total & 12 & 1 & 0 & 1 & 1 & 7 & 3 & 2 & 2 & 2 & 0 & & 3 & 0 & 0 & 0 & 1 & 3 & \\
\hline new & 5 & 0 & 0 & 0 & 0 & 0 & 3 & 0 & 0 & 0 & 0 & & 2 & 0 & 0 & 0 & 1 & 2 & 2 \\
\hline rebuild & 7 & 1 & 0 & 1 & 1 & 7 & 0 & 2 & 2 & 2 & 0 & & 1 & 0 & 0 & 0 & 0 & 1 & \\
\hline & \multicolumn{19}{|c|}{ Number of Physical Space designs (pieces) } \\
\hline total & \multicolumn{19}{|l|}{45} \\
\hline new & \multicolumn{19}{|l|}{24} \\
\hline $\begin{array}{l}\text { rebui } \\
\text { ld }\end{array}$ & \multicolumn{19}{|l|}{21} \\
\hline & \multicolumn{8}{|c|}{ Space utilization } & The ro & ad tra & & & & & & $\begin{array}{l}\text { The } \\
\text { subs }\end{array}$ & e strate & $e^{\text {gre }}$ & \\
\hline total & 32 & & & & & & & & 8 & & & & & & & 5 & & & \\
\hline new & 21 & & & & & & & & 2 & & & & & & & 1 & & & \\
\hline $\begin{array}{l}\text { rebui } \\
\text { ld }\end{array}$ & 11 & & & & & & & & 6 & & & & & & & 4 & & & \\
\hline & $\begin{array}{l}\text { Lan } \\
\text { d } \\
\text { layo }\end{array}$ & $\begin{array}{l}\text { Her } \\
\text { reg } \\
\text { ion }\end{array}$ & $\begin{array}{l}\text { tage } \\
\text { nerat }\end{array}$ & & $\begin{array}{l}\text { ommun } \\
y\end{array}$ & $\begin{array}{l}\text { Co } \\
\text { cia } \\
\text { blo }\end{array}$ & $\begin{array}{l}\text { nmer } \\
\text { cks }\end{array}$ & & $\begin{array}{l}\text { walki } \\
\text { gg }\end{array}$ & $\begin{array}{l}\text { bic } \\
\text { le }\end{array}$ & & $\begin{array}{l}\text { bu } \\
\mathrm{s}\end{array}$ & & & $\begin{array}{l}\text { Nois } \\
\mathrm{e} \\
\text { contr }\end{array}$ & $\begin{array}{l}\text { gree } \\
\mathrm{n} \\
\text { spac }\end{array}$ & & $\begin{array}{l}\text { Nater } \\
\text { nt } \\
\text { vetlan }\end{array}$ & \\
\hline
\end{tabular}




\begin{tabular}{|l|l|l|l|l|l|l|l|l|l|l|l|}
\hline & ut & & & & & & & le & ol & e & \\
\hline total & 5 & 3 & 24 & 0 & 0 & 2 & 3 & 3 & 0 & 5 & 0 \\
\hline new & 1 & 0 & 20 & 0 & 0 & 0 & 0 & 2 & 0 & 1 & 0 \\
\hline $\begin{array}{l}\text { rebui } \\
\text { ld }\end{array}$ & 4 & 3 & 4 & 0 & 0 & 2 & 3 & 1 & 0 & 4 & 0 \\
\hline
\end{tabular}

\begin{tabular}{|c|c|c|c|c|c|c|c|c|}
\hline & \multicolumn{8}{|c|}{ Number of implementation mechanisms designed (pieces) } \\
\hline total & \multicolumn{8}{|l|}{14} \\
\hline new & \multicolumn{8}{|l|}{0} \\
\hline $\begin{array}{l}\text { rebuil } \\
\text { d }\end{array}$ & \multicolumn{8}{|l|}{14} \\
\hline & \multicolumn{3}{|c|}{ management } & \multicolumn{3}{|l|}{ social } & \multicolumn{2}{|c|}{ economic } \\
\hline total & \multicolumn{3}{|l|}{10} & \multicolumn{3}{|l|}{1} & \multicolumn{2}{|l|}{3} \\
\hline new & \multicolumn{3}{|l|}{0} & \multicolumn{3}{|l|}{0} & \multicolumn{2}{|l|}{0} \\
\hline \multirow[t]{2}{*}{$\begin{array}{l}\text { rebuil } \\
\mathrm{d}\end{array}$} & \multicolumn{3}{|l|}{10} & \multicolumn{3}{|l|}{1} & \multicolumn{2}{|l|}{3} \\
\hline & $\begin{array}{l}\text { Intelligent } \\
\text { manageme } \\
\text { nt }\end{array}$ & $\begin{array}{l}\text { Policy } \\
\text { control }\end{array}$ & $\begin{array}{l}\text { educational } \\
\text { training }\end{array}$ & $\begin{array}{l}\text { populatio } \\
\mathrm{n}\end{array}$ & $\begin{array}{l}\text { employme } \\
\text { nt }\end{array}$ & $\begin{array}{l}\text { cultur } \\
\mathrm{e}\end{array}$ & $\begin{array}{l}\text { industr } \\
\mathrm{y}\end{array}$ & $\begin{array}{l}\text { mone } \\
\mathrm{y}\end{array}$ \\
\hline total & 1 & 1 & 8 & 0 & 1 & 0 & 2 & 1 \\
\hline new & 0 & 0 & 0 & 0 & 0 & 0 & 0 & 0 \\
\hline $\begin{array}{l}\text { rebuil } \\
\text { d }\end{array}$ & 1 & 1 & 8 & 0 & 1 & 0 & 2 & 1 \\
\hline
\end{tabular}

Quantified the subcategories of ecological design methods at the plot level, As shown in Figure 4, similar to the block level, there are many design methods for residential communities and individual buildings, followed by those for energy, water resources, road traffic and management, with less attention paid to other aspects.

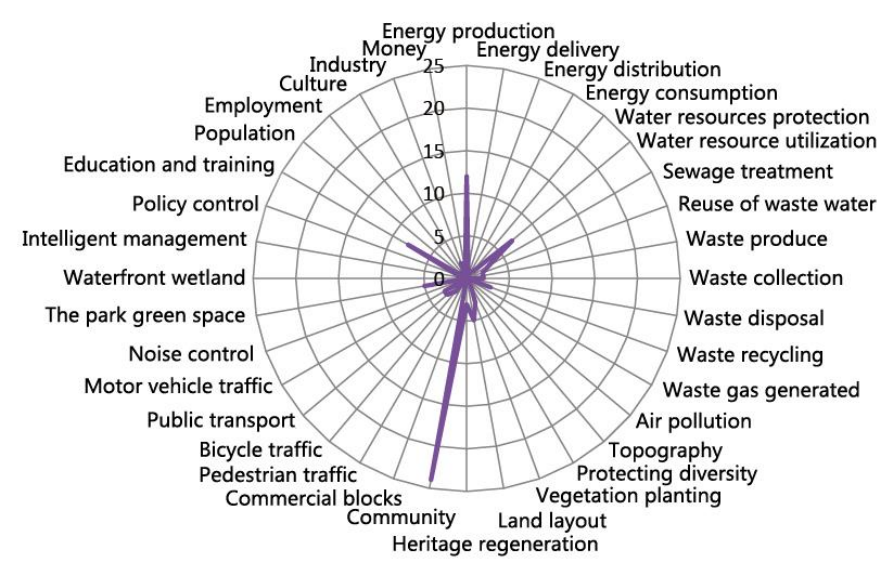

Figure 4. Distribution of ecological design methods on the plot level. Source: The SURBAN Urban Development Best Practices Database. 
Land is mainly used in the reconstruction project within the design method of single annotation, analysis and design method of the total relationship as shown in figure 5, the variation trend of presents such as proportion, compared with block level fluctuation is small, the number of design method is suitable for the rebuilding the whole rolling gently, only in the residential community and monomer design level achieve obvious high value, design method of low quantity to zero.

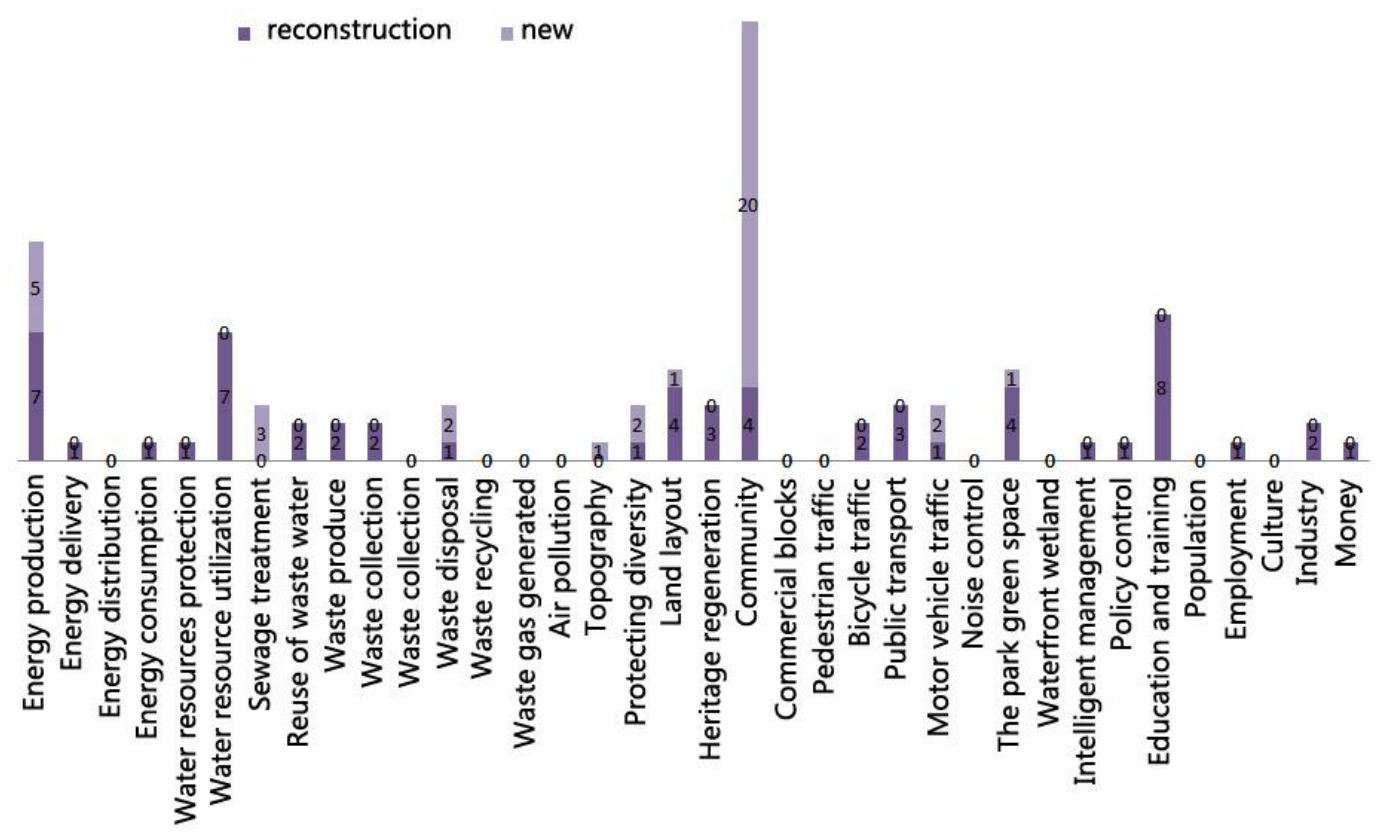

Figure 5. Relationship between the ecological design method mainly applicable to reconstruction and the total volume at the plot level. Source: The SURBAN Urban Development Best Practices Database.

With the decrease of spatial level, the main method types transfer from material energy to physical space .According to the general table of the number distribution of the first and second levels of the ecological design methods in the previous section, it can be found that with the change of the spatial level from large to small, the design method is gradually transferred from the field of material energy design to the field of physical space design, and the strategy in the field of design implementation mechanism is gradually reduced. On the whole, there are few approaches to air quality, topography, biodiversity and social dimensions of design implementation mechanisms in the field of material energy design.

Ecological renovation in Europe pays more attention to energy production, residential communities and intelligent management . Analyze the distribution of the number of three directories, number of visible method can more concentrated in the energy production, space utilization in the community and monomer design of bicycle traffic, motor vehicle traffic in the road traffic, green matrix of the park green space, the management of intelligent management and education training and the types of industry in the economy. Among them, energy production, residential community and intelligent management are the most obvious, which are also the types that European ecological renovation projects pay the most attention to.

\section{Conclusion}

\subsection{Development Trend of ecological design}

Trend of reconstruction and redesign. The overall environment composed of man and nature is a complex and changeable system, which determines that ecological design, as an intervention to man and nature, will not be a simple and linear design process. There is no large open space in the city for a new single design, instead of the old city renovation and redesign. The design methods of European ecological reconstruction projects collected in this paper are based on the reconstruction, reconstruction and redesign of original cities. According to statistics, more than half of the ecological design methods at various spatial levels are 
mainly applicable for reconstruction, as shown in Table 6. It can also be confirmed that the natural law of ecological design is a process of investigation, design, monitoring, feedback and redesign. Planners should constantly review and reflect the previous design in the design process, and integrate public opinions to realize public participation.

Table 6 Relationship between the number of ecological reconstruction design methods and the total amount (red represents more than half). Source: The SURBAN Urban Development Best Practices Database.

\begin{tabular}{|l|l|}
\hline Number of ecological design methods & Block level \\
\hline A total of & 97 \\
\hline reconstruction & 60 \\
\hline
\end{tabular}

Interdisciplinary and multi-field cooperation.Since the 1960s, biologists, scientists, architects and landscape architects have explored ecological design one by one in their respective disciplines, and scholars such as Michael Hage have advocated interdisciplinary and multi-disciplinary research on ecological city design. Urban development is affected by a variety of factors. Environmental problems in cities cannot be solved by planners alone. They cannot be solved without interdisciplinary studies of ecology, sociology, management, economics, information technology and other disciplines. Urban planning and design professionals are increasingly aware of the importance of interdisciplinary, starting from the traditional research on space to a comprehensive study, pay attention to the implementation mechanism of relevant design cooperation.

Combination of intelligence and ecological design.With the progress of science and technology in the world, the ecological planning and design of cities have been supported by science and technology. To develop a large number of renewable energy to replace the limited fossil energy, reduce environmental pollution; GIS GIS technology can be used for land suitability analysis, space simulation and multi-scheme comparison to improve the efficiency and accuracy of the original ecological design. Facilitate more scientific monitoring and management of the operation of various ecological design systems. The proportion of intelligent management in ecological design method also reflects that science and technology, intelligence and wisdom are powerful supports for the future development of ecological design.

Promoting role of the government.Through the statistics of the number of cases in each spatial level and each region where the government is the design unit, the relationship between the number of cases and the total number of cases is analyzed, as shown in Table 7. It is found that the cases promoted by the government at the plot level account for nearly half of the total cases. It can be seen that the government's participation, support and guidance play a vital role in the smooth practice of ecological reconstruction projects.

Table 7 Relationship between the number of cases promoted by the government and the total amount (red represents more than half). Source: The SURBAN Urban Development Best Practices Database.

\begin{tabular}{|l|l|}
\hline The case number & Block level \\
\hline A total of & 42 \\
\hline The government to promote & 19 \\
\hline
\end{tabular}

\section{2. enlightenment}

Comprehensive and coordinated ecological design.Compared with domestic ecological design gimmick, Europe not only stays in the narrow sense of ecological design theory and design level, more emphasis on multiple systems, multidisciplinary cooperation, in the government, planners, the public and other joint efforts, from a technical support, the material space, economic management, social culture, policy, operation, and other areas of the system, ecological design. Among them, the change of government role, the improvement of technology application level and the cultivation of public ecological awareness are 
especially worthy of our country's learning, which are the only way to realize comprehensive ecological design.

Synchronization of design and implementation mechanism. At present, China has accumulated some experience in micro-environment design, such as: energy conservation and emission reduction measures in various systems of material energy flow, compact urban space layout, urban and rural greening system combining point, line and surface, as well as advocating the reform and priority of public transportation, creating a dynamic pedestrian space, etc..The development of ecological civilization in Europe depends on the construction of macro-ecological environment, which must be synchronized with the construction of political, economic and cultural design and implementation mechanisms. We will improve the legal system, strengthen enforcement and supervision, provide corresponding legal protection to ecological builders, punish behaviors that cause ecological damage, increase input in pollution control through the ecological tax system, and improve environmental quality. The concept of ecological economy should be set up, and ecological technological innovation should be promoted to drive economic growth, so as to make industrial development more environmentally friendly and energy-saving. Improve the public ecological awareness, maintain a sustainable living environment, actively choose environmental protection products with green logo when consuming, and reverse drive the development of ecological economy through the change of consumption concept.

\section{References}

Begon, Michael, Colin R. Townsend, and John L.Harper, M.( 2006). Ecology: From Individuals to Ecosystems. Fourth Edi. Blackwell Publishing.

SIM VAN DER RYN, STUART COWAN,M.(1995). An Introduction to Ecological Design. Washington: Island Press Publishing

Xiang,W.-N.(2014). Doing real and permanent good in landscape and urban planning:Ecological wisdom for urban sustainability. Landscape and Urban Planning, 121:65-69.

Alex Wilson, Jenifer L etc. Site planning and design In: Alex Wilson ed. Green Development. New York: John Wiley \& Sons, Inc, 1998,P2-24, P124-156.

Leiss, W. (1994). The domination of nature. McGill-Queen's University Press.

Sim Vander Ryn, Stuart Cowan. Sustainahility and design In: Sim Vander Ryn ed. Ecological design Washington: Island Press, 1996, P3-33.

McHarg, L, (1995). Wiley Series in Sustainable Design:Design with Nature. New Jersey:Wiley.

Carson, R. Silent Spring. (2003). Boston: Houghton Mifflin Harcourt.

Simmonds, M.(2000). Landscape Architecture. Yu Kongjian, WANG Zhifang, SUN Peng, Beijing: China Building Industry Press.

Huang Guangyu, Chen Yong, M.(2002). Ecological city theory and planning and Design methods, Beijing: Science Press, p83.

Xu XingJing. 'Study on the Application of European Eco-city Construction to the development of Chongming Eco-Island', Tongji university, 2014.

$\mathrm{Fu}$ Zhenzhen, J.A. 'Case study method - Using case studies to explore the nature behind the phenomenon', Library information knowledge, 2010(1), p20-25.

Liu Ping, Wang Rusong. 'Discussion on ecological design method of urban living environment', Acta ecologica sinica, 2001(6), p997-1002.

Wu Zhiqiang, M,(2009).Cities Beyond Oil, Beijing: China Building Industry Press. 
Liu Conghong, Pan Lei, Li Yifan. Research and enlightenment on adaptive reuse of foreign old buildings, Journal of Tianjin University,2007(7):370-372.

Qiu Baoxing, Inheritance and Transcendence -- The Differences between Chinese and Western original Ecological Civilization view and its enlightenment to modern Ecological City, urban planning, 2011 (05) , P9-19.

Rodney R W. M,(2009). Planning and construction of ecological city, Shanghai: Tongji University Press.

He Bibo, Huang Lingxiang, Reconstruction and Reconstruction of foreign eco-city construction model and its enlightenment to Our country, Ecological economy, 2011 (12) :P183-187.

MA Jiaoguo.YANG Yongchun, The practice of eco-city construction abroad and its enlightenment to China, International urban Planning,2006,21(2).

Huang Zhaoyi, Yang Dongyuan, A review of ecological city theory at home and abroad, urban planning, 2001(01): P59-65.

Zhao Hongbin, Research on architectural Design Process based on design Methodology, Architecture and Culture, 2014 (06):P148-149. 